\title{
Measuring HIV- and TB-related stigma among health care workers in South Africa: a validation and reliability study
}

\author{
E. Wouters, ${ }^{* \dagger}$ C. Masquillier, ${ }^{*}$ N. Sommerland, ${ }^{*}$ M. Engelbrecht, ${ }^{\dagger}$ A. J. Van Rensburg, ${ }^{\dagger}$ G. Kigozi, ${ }^{\dagger}$ \\ A. $\operatorname{Rau}^{\dagger}$
}

*Department of Sociology and Centre for Longitudinal and Life Course Studies, University of Antwerp, Antwerp, Belgium; ${ }^{\dagger}$ Centre for Health Systems Research and Development, University of the Free State, Bloemfontein, South Africa

S U M M ARY

SETTING: Recent evidence indicates that human immunodeficiency virus (HIV) and tuberculosis (TB) related stigma act as a key barrier to the utilisation of associated occupational health services by South African health care workers (HCWs). It also highlights a dearth of appropriate tools to measure HIV and TB stigma among HCWs.

OвJECTIVE: To test four scales measuring different aspects of stigma: respondent's external stigma (RES) and others' external stigma (OES) towards TB as well as HIV across different professional categories of HCWs. DESIGN: The current study employs data from a study on HIV and TB stigma among HCWs, a cluster randomised controlled trial for the collection of data among $882 \mathrm{HCWs}$ in the Free State Province of South Africa. Confirmatory factor analyses and structural equation modelling were used to assess the validity and reliability of the scales.

RESULTS: All four scales displayed adequate internal construct validity. Subsequent analysis demonstrated that all four scales were metric-invariant, and that the OES scales were even scalar-invariant across patient and support staff groups. The scales displayed good reliability and external construct validity.

CONCLUSION: Our results support the use of the scales developed to measure TB and HIV stigma among HCWs. Further research is, however, needed to fine tune the instruments and test them across different resource-limited countries.

KEY WORDS: stigma; South Africa; HCWs; reliability; validity
THE DEADLY human immunodeficiency virus (HIV) and tuberculosis (TB) co-epidemic has had a severe impact on South Africa and its health system. ${ }^{1}$ With 7.0 million South Africans living with HIV, the country has the world's highest number of infected people. ${ }^{2}$ South Africa also has one of the most severe TB epidemics in the world: in 2015, South Africa had the highest incidence of TB (834 per 100000 population) and 19613 reported cases of rifampicinor multidrug-resistant (MDR) TB. ${ }^{3}$ In addition, both epidemics are intricately intertwined, with approximately $73 \%$ of new TB cases co-infected with HIV. ${ }^{4}$

Apart from the massive burden of disease and the subsequent workload for an already crippled health system, ${ }^{5-7}$ the co-epidemic is also affecting the health care workforce. Occupational exposure to TB constitutes a major health risk for health care workers (HCWs): large patient numbers and the resulting overcrowded health facilities, combined with poorly implemented infection control strategies, render HCWs three times more likely to acquire TB than the general population. ${ }^{8-10} \mathrm{~TB}$ is thus officially classified as an occupational disease. The HIV epidemic also affects the workforce because of the mutually reinforcing epidemiology of HIV and TB: estimates of HIV prevalence among South African HCWs range from $11.5 \%$ to $20.0 \% .^{11}$

Recent evidence has demonstrated that providing HIV and TB services to HCWs at work is costeffective, and is preferred by the majority of HCWs. ${ }^{12,13}$ Workplace health services for TB and HIV/AIDS (acquired immune-deficiency syndrome) are thus an essential part of any strategy for the strengthening of health systems. ${ }^{14}$ However, a review paper has demonstrated that HIV- and TB-related stigma and discrimination are the key barriers to the use of these services and thus to the success of workplace health programmes. ${ }^{15}$ This renders the development and testing of stigma-reduction interventions among HCWs a clear research priority.

A first step towards such a stigma-reduction intervention is the development and testing of

Correspondence to: Edwin Wouters, Department of Sociology, University of Antwerp, Sint-Jacobstraat 2, BE-2000 Antwerp, Belgium. e-mail: edwin.wouters@uantwerpen.be

Article submitted 10 October 2016. Final version accepted 5 June 2017. 
appropriate tools to measure both HIV and TB stigma among the health care workforce (towards HCWs, not patients), as there are currently very few HIV and TB stigma-measurement scales that specifically target people working in the health system. The only available tools-published recently by Wouters et al.-have been tested only in a small sample of HCWs, and did not include multiple group testing to account for different outcomes across different professional categories. ${ }^{16}$ The current validation study aims to address these shortcomings by testing a range of scales measuring different aspects of stigma: the respondent's and colleagues' external stigma towards TB as well as HIV across different professional categories working in the health care setting.

\section{METHODS}

The present study employed the baseline data of a cluster randomised controlled trial-Towards a health-enabling working environment: developing and testing interactions to decrease HIV and TB sitgma among health care workers in the Free State, South Africa-aimed at reducing levels of HIV and TB stigma among HCWs in the Free State Province of South Africa. The study protocol was approved by the Ethics Committee of the Faculty of Health Science of the University of the Free State, Bloemfontein, South Africa (ECUFS 55/2015).

The study aims to scientifically assess the extent and sources of HIV- and TB-related stigma among HCWs and to develop and test evidence-based stigma-reduction interventions. For this goal, a random sample of $882 \mathrm{HCWs}$-both patient staff (i.e., doctors, nurses; 446) and support staff (i.e., messengers, cleaners, administrative staff; $n=436$ ) working in eight hospitals in the Free State-was drawn from the health care workforce register. For each hospital, HCWs were categorised separately according to professional group (support, management and administration, doctors, nurses, and allied). A list of random numbers was generated to sample HCWs proportionate to size so that each group was represented. In total, $24.0 \%$ of HCWs were not able to participate (no longer working there, unavailable, refused participation) and had to be replaced by a random selection of HCWs with similar profiles (hospital and professional category). After obtaining written informed consent from all participants, trained field workers provided participants with standard questionnaires that were completed in a self-administered process.

\section{Measures}

The questionnaire contained four stigma scales that had been previously piloted in a small sample and reported by Wouters et al.: ${ }^{16} 1$ ) the Others' External
Stigma (OES) scales measure perceptions, attitudes and behaviours that respondents witness being enacted, or perceive as existing, among other HCWs (referred to also as 'colleagues') in the hospital (scale $1=$ HIVOES; scale $2=$ TBOES); and 2) the Respondent's External Stigma (RES) scales measure respondents' perceptions, attitudes and behaviours towards other HCWs in the hospital (scale $3=$ HIVRES; scale 4 = TBRES).

The outcomes of the pilot study were used to minimise the number of items per stigma subscale, as the HCWs' time was limited. Apart from the four stigma scales (listed in Table 1) to be tested, the survey included a series of sociodemographic questions (age, sex, occupation, education). The pilot study also assessed HIV- (10 items) and TB-related knowledge (10 items) among HCWs, as studies have repeatedly shown a negative association between knowledge and stigma. ${ }^{17,18}$ Finally, previous research clearly indicates that stigma and confidentiality are associated. ${ }^{15,19,20}$ The survey thus included a series of questions on confidentiality in the workplace (e.g., 'do you think confidentiality is maintained in your occupational health unit?').

\section{Data analysis}

Our analytical strategy consisted of the following four steps: 1) confirmatory factor analysis (CFA) testing for internal construct validity, 2) reliability testing (Cronbach's $\alpha$ ), 3 ) testing of configural, metric and scalar invariance across the two subgroups (patient staff and support staff) using differences in $\chi^{2}$, and 4) structural equation modelling to test for external construct validity (correlations between stigma scales and with TB and HIV knowledge and confidentiality). The full analytical strategy is explained in the Appendix.* All analyses were performed using MPlus v7.4 (Muthén \& Muthén, Los Angeles, CA, USA).

\section{RESULTS}

Population characteristics and presentation of the items

The characteristics of our population are given in Table 2. Table 1 shows the different items ascribed to the different stigma scales, as well as the spread of HCW responses.

\section{Confirmatory factor analyses: internal construct validity}

A series of CFAs was executed to assess the internal construct validity of the four scales. Table 1 shows the

\footnotetext{
* The appendix is available in the online version of this article, at http://www.ingentaconnect.com/content/iuatld/ijtld/2017/ 00000021/a00111s1/art00005
} 
Table 1 Four stigma scales, * factor loadings, reliability estimate and goodness-of-fit indices $(n=882$, except for HIVOES, $n=881)$

\begin{tabular}{|c|c|c|c|c|}
\hline & & $\begin{array}{l}\text { Standardised } \\
\text { loading }\end{array}$ & \multicolumn{2}{|c|}{ Mean \pm SD } \\
\hline \multicolumn{5}{|c|}{ HIVOES $(\alpha=0.792)$} \\
\hline \multicolumn{2}{|c|}{ Some of my co-workers in this hospital look down on HCWs who they think may be } & 0.706 & \multicolumn{2}{|c|}{$1.99 \pm 0.801$} \\
\hline $\begin{array}{l}\text { There } \\
\text { inv }\end{array}$ & o-workers who are & 0.688 & \multicolumn{2}{|c|}{$2.13 \pm 0.825$} \\
\hline \multicolumn{2}{|c|}{ Some HCWs who are suspected of having HIV are rejected by others in the workplace } & 0.716 & \multicolumn{2}{|c|}{$1.99 \pm 0.737$} \\
\hline \multicolumn{2}{|c|}{ Other HCWs in this hospital are afraid of catching HIV from colleagues who care for } & 0.681 & \multicolumn{2}{|c|}{$2.05 \pm 0.805$} \\
\hline \multicolumn{5}{|c|}{ HIVRES $(\alpha=0.783)$} \\
\hline clos & & 0.524 & \multirow{3}{*}{\multicolumn{2}{|c|}{$\begin{array}{l}1.87 \pm 0.775 \\
1.65 \pm 0.755 \\
1.61 \pm 0.701\end{array}$}} \\
\hline $\mathrm{HCW}$ & & 0.736 & & \\
\hline HIV-p & & 0.757 & & \\
\hline \multicolumn{2}{|c|}{ Doctors and nurses with HIV who are otherwise in good health should continue } & 0.727 & \multicolumn{2}{|c|}{$1.50 \pm 0.633$} \\
\hline \multicolumn{5}{|c|}{$\operatorname{TBOES}(\alpha=0.841)$} \\
\hline $\mathrm{HCW}$ & & 0.749 & \multicolumn{2}{|c|}{$1.98 \pm 0.741$} \\
\hline \multicolumn{2}{|c|}{ Some HCWs in this hospital avoid contact with co-workers who they think may have TB } & 0.812 & \multicolumn{2}{|c|}{$1.96 \pm 0.715$} \\
\hline \multicolumn{2}{|c|}{$\begin{array}{l}\text { Some HCWs in this hospital would not want to eat or drink with a co-worker who they } \\
\text { think has TB }\end{array}$} & 0.674 & \multicolumn{2}{|c|}{$2.12 \pm 0.843$} \\
\hline \multirow{2}{*}{\multicolumn{2}{|c|}{$\begin{array}{l}\text { Some HCWs in this hospital are stigmatised when others find out that they have } \\
\text { undergone TB screening } \\
\text { I have noticed that some other HCWs in this hospital feel uncomfortable to work near } \\
\text { co-workers with TB }\end{array}$}} & 0.632 & 2.00 & $2.12-0.045$ \\
\hline & & 0.710 & 2.92 & .808 \\
\hline \multicolumn{5}{|c|}{ TBRES $(\alpha=0.657)$} \\
\hline I do $n$ & uberculosis treatment & 0.682 & \multirow{3}{*}{\multicolumn{2}{|c|}{$\begin{array}{l}1.70 \pm 0.677 \\
2.31 \pm 0.807 \\
1.80 \pm 0.666\end{array}$}} \\
\hline I am & & 0.374 & & \\
\hline If I th & ame room & 0.788 & & \\
\hline & SRMR & RMSEA & $\mathrm{CFI}$ & TLI \\
\hline HIVOES & 0.038 & 0.142 & 0.919 & 0.757 \\
\hline HIVRES & 0.012 & 0.034 & 0.995 & 0.984 \\
\hline TBOES & 0.031 & 0.084 & 0.958 & 0.916 \\
\hline TBRES & 0 & 0 & 1 & 1 \\
\hline
\end{tabular}

*All items were rated on a four-point Likert scale (totally agree, agree, disagree, totally disagree).

HIVOES = others' stigmatising attitudes, perceptions and behaviours towards HIV; SD = standard deviation; HCW = health care worker; HIV = human immunodeficiency virus; HIVRES = respondent's stigma towards HIV; TB = tuberculosis; TBOES=others' stigmatising attitudes, perceptions and behaviours towards TB; TBRES = respondent's stigma towards TB; SRMR = standardised root mean square residual; RMSEA = root mean square error of approximation; $C F I=$ Confirmatory Fit Index; TLI = Tucker-Lewis Index.

Table 2 Sample descriptors

\begin{tabular}{lc}
\hline & $n(\%)$ \\
\hline Sex & \\
Male & $249(28.3)$ \\
Female & $631(71.7)$ \\
Age & 875 \\
& (mean age 43.62 years \pm SD 9.9) \\
Education level & \\
None & $4(0.5)$ \\
Primary & $48(5.4)$ \\
Secondary & $154(17.5)$ \\
Matric & $306(34.7)$ \\
Diploma & $240(27.2)$ \\
Degree & $130(14.7)$ \\
Race & \\
Black & $774(87.8)$ \\
Coloured & $34(3.9)$ \\
White & $70(7.9)$ \\
Asian & $4(0.5)$ \\
Years working in the hospital & 882 \\
Professional group & (mean 11.64 years \pm SD 9.6) \\
Patient care & \\
Support staff & $446(50.7)$ \\
\hline
\end{tabular}

$\mathrm{SD}=$ standard deviation factor loadings of the different items onto the different theory-based scales.

The original model measuring the respondents' stigma towards HIV (HIVRES) comprised five items but did not fit the data well. One item ('I would feel comfortable being close friends with a health care worker who is known to be HIV-positive') also did not load well onto the factor $(\lambda=0.372)$. When we deleted this item, the factor with four items fitted the data well (root mean square error of approximation $[$ RMSEA $]=0.034$; Confirmatory Fit Index $[\mathrm{CFI}]=$ 0.995; Tucker-Lewis Index $[\mathrm{TLI}]=0.984$; standardised root mean square residual $[\mathrm{SRMR}]=0.012$ ), whereas all items loaded well onto this factor. The scale measuring colleagues' stigmatising attitudes, perceptions and behaviours towards HIV (HIVOES) yielded a borderline fit, with SRMR demonstrating a good fit (0.038) and the CFI (0.919) suggesting an acceptable fit; however, the RMSEA (0.142) and TLI (0.757) were a poor fit. The CFA, however, displayed 
Table 3 Invariance model comparisons for the four stigma scales ( $n=882$, except for HIVOES $n=881$ )

\begin{tabular}{|c|c|c|c|c|c|c|}
\hline & $\chi^{2}$ & $\mathrm{df}$ & CFI & TLI & RMSEA & SRMR \\
\hline \multicolumn{7}{|l|}{ HIVOES } \\
\hline M1: configural invariance & 40.587 & 4 & 0.915 & 0.744 & 0.144 & 0.041 \\
\hline M2: metric invariance & 41.665 & 7 & 0.919 & 0.861 & 0.106 & 0.045 \\
\hline M3: scalar invariance & 50.004 & 10 & 0.907 & 0.888 & 0.095 & 0.050 \\
\hline $\begin{array}{l}\text { M1 vs. M2 } \\
\text { M2 vs. M3 }\end{array}$ & $\begin{array}{l}\Delta \chi^{2} \\
2.540 \\
4.297\end{array}$ & $\begin{array}{c}\Delta \mathrm{df} \\
3 \\
3\end{array}$ & $\begin{array}{c}P \text { value } \\
0.468 \\
0.231\end{array}$ & & & \\
\hline \multicolumn{7}{|l|}{ HIVRES } \\
\hline M1: configural invariance & 6.279 & 4 & 0.994 & 0.982 & 0.036 & 0.014 \\
\hline M2: metric invariance & 8.208 & 7 & 0.997 & 0.994 & 0.020 & 0.025 \\
\hline M3: scalar invariance & 18.204 & 10 & 0.978 & 0.974 & 0.043 & 0.027 \\
\hline $\begin{array}{l}M 1 \text { vs. M2 } \\
M 2 \text { vs. } M 3\end{array}$ & $\begin{array}{c}\Delta \chi^{2} \\
1.842 \\
11.315\end{array}$ & $\begin{array}{c}\Delta \mathrm{df} \\
3 \\
3\end{array}$ & $\begin{array}{c}P \text { value } \\
0.606 \\
0.011\end{array}$ & & & \\
\hline \multicolumn{7}{|l|}{ TBOES } \\
\hline M1: configural invariance & 44.581 & 10 & 0.953 & 0.907 & 0.089 & 0.034 \\
\hline M2: metric invariance & 49.809 & 14 & 0.952 & 0.931 & 0.076 & 0.035 \\
\hline M3: scalar invariance & 65.888 & 18 & 0.936 & 0.928 & 0.078 & 0.041 \\
\hline $\begin{array}{l}M 1 \text { vs. } M 2 \\
M 2 \text { vs. } M 3\end{array}$ & $\begin{array}{c}\Delta \chi^{2} \\
0.721 \\
17.071\end{array}$ & $\begin{array}{c}\Delta \mathrm{df} \\
4 \\
4\end{array}$ & $\begin{array}{c}P \text { value } \\
0.949 \\
0.002\end{array}$ & & & \\
\hline \multicolumn{7}{|l|}{ TBRES } \\
\hline M1: configural invariance & 0 & 0 & 1 & 1 & 0 & 0 \\
\hline M2: metric invariance & 4.325 & 2 & 0.985 & 0.954 & 0.051 & 0.041 \\
\hline M3: scalar invariance & 15.006 & 4 & 0.927 & 0.891 & 0.079 & 0.068 \\
\hline $\begin{array}{l}M 1 \text { vs. M2 } \\
M 2 \text { vs. M3 }\end{array}$ & $\begin{array}{c}\Delta \chi^{2} \\
4.325 \\
12.621\end{array}$ & $\begin{array}{c}\Delta \mathrm{df} \\
2 \\
2\end{array}$ & $\begin{array}{c}P \text { value } \\
0.115 \\
0.002\end{array}$ & & & \\
\hline
\end{tabular}

HIVOES = others' stigmatising attitudes, perceptions and behaviours towards human immunodeficiency virus; $\mathrm{df}=\mathrm{degrees}$ of freedom; $\mathrm{CFI}=\mathrm{Confirmatory} \mathrm{Fit}$ Index; TLI=Tucker-Lewis Index; RMSEA = root mean square error of approximation; SRMR=standardised root mean square residual; HIVRES=respondent's stigma towards HIV; TBOES = others' stigmatising attitudes, perceptions and behaviours towards TB; TBRES = respondent's stigma towards TB; HIV = human immunodeficiency virus; TB = tuberculosis.

sufficiently high loadings of the four items onto the factor.

The first TB scale assessed the respondent's stigma towards TB using only three items (TBRES). This caused the model to be just identified, resulting in an inability to assess the model fit. Two items loaded well onto the factor, but the third item ('I am cautious of coworkers who are on TB treatment') did not sufficiently load onto the factor $(\lambda=0.374)$. Deleting this item, however, would result in a model that was underidentified. The model testing the scale for measuring stigmatising attitudes towards TB among HCWs in the respondent's entourage (TBOES) displayed an acceptable fit to the data. The factor loadings indicated that all five items loaded well onto the factor.

\section{Scale reliability}

The resulting factors were subjected to a reliability analysis (Table 1). All but one of the final scales displayed good reliability (Cronbach's $\alpha>0.7$ ). As expected, the three-item factor TBRES only produced a Cronbach's $\alpha$ of 0.657 .

\section{Multiple-group confirmatory factor analyses}

Second, multiple-group CFAs were used to examine the extent to which properties and interpretations of the stigma scores generalised across the two selected professional groups: patient staff and support staff (Table 3).

In a first step, configural invariance was tested. The fit of the four models was generally satisfactory: only the HIVOES scale displayed a borderline fit. All factor loadings were $>0.4$, except for one item ('I am cautious of co-workers who are on TB treatment') of the REXT-TB scale that had a loading of 0.445 in the medical staff group, but only 0.256 in the support staff group. It can thus be concluded that the four scales exhibited configural invariance across the two professional groups, i.e., each stigma scale was associated with identical item sets across the two groups.

After configural invariance had been established, testing for metric invariance was conducted using a $\chi^{2}$ difference $\left(\Delta \chi^{2}\right)$ test for two nested models. The four metric-invariant models displayed an acceptable fit. More importantly, the increase in $\chi^{2}$ was not significant for each of the four scales, indicating invariance of the factor loadings across the two groups. Hence, this level of invariance provided evidence that the corresponding common factors had the same meaning across groups.

In a final step, testing for scalar invariance, equal 
Table 4 Estimated correlation matrix of latent constructs (HIVOES, TBOES, HIVRES and TBRES; $n=881$ )

\begin{tabular}{lccc}
\hline \multicolumn{1}{c}{ HIVOES } & HIVRES & TBOES & TBRES \\
\hline Group: patient care & & & \\
HIVOES & $0.157^{*}$ & $0.830^{+}$ & $0.511^{\dagger}$ \\
HIVRES & & $0.198^{+}$ & $0.360^{\dagger}$ \\
TBOES & & & $0.705^{\dagger}$ \\
Group: others & & & \\
HIVOES & -0.038 & $0.789^{+}$ & $0.531^{\dagger}$ \\
HIVRES & & -0.022 & 0.125 \\
TBOES & & & $0.705^{\dagger}$ \\
\hline
\end{tabular}

$* P<0.05$

${ }^{+} p<0.001$

HIVOES = others' stigmatising attitudes, perceptions and behaviours towards $\mathrm{HIV}$; TBOES = others' stigmatising attitudes, perceptions and behaviours towards TB; HIVRES = respondent's stigma towards HIV; TBRES = respondent's stigma towards TB; HIV = human immunodeficiency virus; $\mathrm{TB}=$ tuberculosis.

factor loadings and equal indicator intercepts (i.e., indicator means) across groups are required. All four models displayed a satisfactory fit to the data (with the exception of the HIVOES scale, where the fit indices displayed a mixed pattern). The additional restriction did not result in a significant increase in $\chi^{2}$ for both OES scales-measuring the perceived stigmatising attitudes of the co-workers-indicating that the error variances of items loading on the same factor were identical. We can thus compare the latent means of the HIVOES and TBOES scales across the two professional groups. The restriction, however, did result in a significant increase in $\chi^{2}$ for both RES scales, meaning that the two scales are not fully scalar invariant across the two groups and that we could not compare the latent means across the groups.

\section{Structural equation modelling: external construct validity}

First, we looked at the correlations between the different types of stigma (Table 4). Across both

Table 5 Structural equation models testing the correlations between the various stigma scales and 1) confidentiality, 2) HIV knowledge and 3) TB knowledge-each time controlled for the impact of age, gender and education $(n=869)$

\begin{tabular}{lcccc}
\hline & HIVOES & HIVRES & TBOES & TBRES \\
\hline $\begin{array}{l}\text { Confidentiality } \\
\quad \text { Patient care }\end{array}$ & $0.326^{*}$ & 0.047 & $0.277^{*}$ & $0.130^{+}$ \\
$\quad$ Others & $0.204^{*}$ & -0.049 & $0.180^{+}$ & $0.195^{+}$ \\
$\quad \begin{array}{l}\text { Knowledge } \\
\quad \text { HIV knowledge }\end{array}$ & & & & \\
$\quad$ Patient care & $-0.104^{+}$ & -0.108 & -0.056 & -0.074 \\
$\quad$ Others & -0.075 & $-0.110^{+}$ & -0.089 & $-0.150^{+}$ \\
TB knowledge & & & & \\
$\quad$ Patient care & $-0.176^{*}$ & $-0.164^{*}$ & $-0.155^{*}$ & $-0.185^{*}$ \\
$\quad$ Others & 0.011 & -0.043 & 0.008 & $-0.108^{+}$ \\
\hline
\end{tabular}

* $P<0.001$

${ }^{+} P<0.05$.

${ }^{\ddagger} p<0.01$.

$\mathrm{HIV}=$ human immunodeficiency virus; TB = tuberculosis; HIVOES = others stigmatising attitudes, perceptions and behaviours towards HIV; TBOES = others' stigmatising attitudes, perceptions and behaviours towards TB: HIVRES = respondent's stigma towards HIV; TBRES = respondent's stigma towards TB. groups, we observed moderate-to-strong correlations between HIVOES and TBOES and between TBRES and TBOES. To test the external construct validity of the four scales across the two groups, we tested a series of structural equation models (SEMs; Table 5). In each model, we controlled for age, sex and education. As hypothesised, the level of confidentiality weakly (but significantly) correlated with the respondent's perception of their colleagues' stigmatising attitudes (TBOES and HIVOES), thereby supporting our claim that the developed scales measured what they were designed to measure. The SEMs also supported the external construct validity of scales measuring the respondent's own stigmatising attitudes (TBRES and HIVRES), as these scales correlated weakly (but significantly) with their respective knowledge scores. Only the correlation between the HIVRES scale and HIV knowledge among the patient staff was not significant $(P=0.065)$.

\section{DISCUSSION}

There is a dearth of validated HIV and TB stigma scales that explicitly target different HCW groups. Measuring a complex construct, such as HIV or TB stigma, in this subpopulation is complex, and requires sufficient attention to be paid to the validity and reliability of applied instruments. We wished to validate and test the psychometric properties of a series of measures of HIV and TB stigma in a health care setting.

The results of the CFAs demonstrated that the four scales measuring external stigma towards HIV (1) and TB (2) among colleagues and the external stigma towards HIV (3) and (4) among respondents displayed acceptable internal construct validity. Multiple group analyses demonstrated that all scales were metric-invariant across the two professional groups, indicating that stigma constructs had the same meaning across groups; quantitative group comparisons of estimated factor variances and covariances were therefore defensible. ${ }^{21,22}$ Two scales were scalar-invariant, allowing for defensible group comparisons of both observed and factor means as well as factor variances and covariances. ${ }^{21,22}$

The strong correlation-across both professional groups-between the two OES stigma scales provides evidence of the existence of a double stigma, as theoretically developed by Daftary. ${ }^{23}$ We assessed the external construct validity of the four scales by testing a series of SEMs. In accordance with previous studies, ${ }^{15,16,20}$ the respondent's perceptions of their colleagues' externalising stigma (OES) was negatively correlated with the level of perceived confidentiality in the hospital. These results support the external construct validity of the scales, as they are in accordance with those of a recent study by Kahn et al., which identified a clear relationship between 
perceived stigma levels, perceived confidentiality in the facility and the uptake of occupational health services. ${ }^{24}$ As demonstrated previously, knowledge about TB and HIV negatively correlated with the respondents' own stigmatising attitudes, supporting the external construct validity of the TBRES and HIVRES scales. ${ }^{17,25,26}$

The results and implications of the present study should be interpreted in view of its two main limitations. First, the scales employed in this validation study were developed to be as concise as possible to make them suitable for inclusion in large-scale studies, which usually explore a wide range of concepts and thus have limited space for each individual concept. This has resulted in scales consisting of only three items, leading to justidentified CFA models, the inability to drop items with low loadings and the borderline fit of some of the models. Second, our study should be considered as the first step in the development and testing of a series of parallel scales measuring the stigmatising attitudes among HCWs towards HIV and TB in South Africa. Results may not be generalisable to alternative settings, thereby necessitating further work on these instruments in other facilities and regions.

The use of appropriate scales is a crucial element in research designed to develop and test interventions for the reduction of HIV and TB stigma in health care settings. The current study pushed the boundaries of current knowledge by rigorously testing four parallel scales measuring TB and HIV stigma in a health care setting. Our study aims to enable future studies to further validate the scales and, if successful, employ these scales to 1) identify which type of stigma hampers the use of occupational health services, 2) develop appropriate stigma-reduction interventions and 3) assess the impact of these interventions by comparing the factor scores of scalar-invariant scales over time.

\section{Acknowledgements}

The authors thank the health care workers interviewed for their time and energy in sharing their views and experiences; and the Free State Department of Health for their support.

This study was funded by the VLIR-UOS Research Foundation Flanders, Brussels; and the Research Fund of the University of Antwerp, Antwerp, Belgium.

Conflicts of interest: none declared.

\section{References}

1 Wouters E, van Rensburg D, Meulemans H. The National Strategic Plan of South Africa: what are the prospects of success after the repeated failure of previous AIDS policy? Health Policy Plan 2010; 25: 171-185.

2 UNAIDS. HIV and AIDS estimates 2015. Geneva, Switzerland: UNAIDS, 2015. http://www.unaids.org/en/regionscountries/ countries/southafrica. Accessed July 2017.

3 World Health Organization. Global tuberculosis report, 2016. Geneva, Switzerland: WHO, 2016.
4 Department of Health. Annual performance plan 2012/132014/15. Pretoria, South Africa: Department of Health, Republic of South Africa, 2012.

5 Wouters E, Van Rensburg H C J, Van Loon F, Meulemans H. State of the ART programme: clinical effectiveness and physical and emotional quality-of-life improvements in the Free State Province, South Africa. AIDS Care 2009; 21: 1401-1411.

6 Abdool Karim S S, Churchyard G J, Abdool Karim Q, Lawn S D. HIV infection and tuberculosis in South Africa: an urgent need to escalate the public health response. Lancet 2009; 374 : 921-933.

7 Heunis J C, Wouters E, Norton W E, et al. Patient- and deliverylevel factors related to acceptance of HIV counseling and testing services among tuberculosis patients in South Africa: a qualitative study with community health workers and program managers. Implement Sci 2011; 6: 10.

8 Joshi R, Reingold A L, Menzies D, Pai M. Tuberculosis among health-care workers in low- and middle-income countries: a systematic review. PLoS Med 2006; 3: e494.

9 University Research Co South Africa. Tuberculosis in healthcare workers: findings from South Africa. Tygerberg, South Africa: URC \& Desmond Tutu Tuberculsosis Centre, 2013.

10 O’Donnell M R, Jarand J, Loveday M, et al. High incidence of hospital admissions with multidrug-resistant and extensively drug-resistant tuberculosis among South African health care workers. Ann Intern Med 2010; 153: 516-522.

11 Adamsi S, Ehrlichi R, Ismailii N, Quaili Z, Jeebhayi M F. Occupational health challenges facing the department of health: protecting employees against tuberculosis and caring for former mineworkers with occupational health disease. In: Padarath A, English R, eds. South African Health Review 2012/ 13. Durban, South Africa: Health Systems Trust, 2013: pp 6782.

12 Feeley F G, Collier A C, Richards S C, Van der Borght S F M, Rinke de Wit T F. A successful workplace program for voluntary counseling and testing and treatment of HIV/AIDS at Heineken, Rwanda. Int J Occup Environ Health 2007; 13: 99_ 106.

13 Corbett E L, Marston B, Churchyard G J, De Cock K M. Tuberculosis in sub-Saharan Africa: opportunities, challenges, and change in the era of antiretroviral treatment. Lancet 2006; 367: 926-937.

14 Ncayiyana D. Doctors and nurses with HIV and AIDS in subSaharan Africa. BMJ 2004; 11: 584-585.

15 Nyblade L, Stangl A, Weiss E, Ashburn K. Combating HIV stigma in health care settings: what works? J Int AIDS Soc 2009; 12: 15 .

16 Wouters E, Rau A, Engelbrecht M, et al. The development and piloting of parallel scales measuring external and internal HIV and tuberculosis stigma among healthcare workers in the Free State Province, South Africa. Clin Infect Dis 2016; 62 (Suppl 3): S244-S254.

17 Fay H, Baral S, Trapence G, et al. Stigma, health care access, and HIV knowledge among men who have sex with men in Malawi, Namibia, and Botswana. AIDS Behav 2011; 15: 10881097.

18 Yang H, Li X, Stanton B, Fang X, Lin D, Naar-King S. HIVrelated knowledge, stigma, and willingness to disclosure: a mediation analysis. AIDS Care 2006; 18: 717-724.

19 Coreil J, Mayard G, Simpson K M, Lauzardo M, Zhu Y, Weiss M. Structural forces and the production of TB-related stigma among Haitians in two contexts. Soc Sci Med 2010; 71: 14091417.

20 Nyblade L, Jain A, Benkirane M, et al. A brief, standardized tool for measuring HIV-related stigma among health facility staff: results of field testing in China, Dominica, Egypt, Kenya, Puerto Rico and St. Christopher \& Nevis. J Int AIDS Soc 2013; 16 (Suppl 2): 18718. 
21 Dimitrov D M. Testing for factorial invariance in the context of construct validation. measurement and evaluation in counseling and development. Meas Eval Counsel Dev 2010; 43: 121-149.

22 Gregorich S E. Do self-report instruments allow meaningful comparisons across diverse population groups? Testing measurement invariance using the confirmatory factor analysis framework. Med Care 2006; 44 (Suppl 3): S78-S94.

23 Daftary A. HIV and tuberculosis: the construction and management of double stigma. Soc Sci Med 2012; 74: 1512 1519.
24 Khan R, Yassi A, Engelbrecht M C, Nophale L, van Rensburg A J, Spiegel J. Barriers to HIV counselling and testing uptake by health workers in three public hospitals in Free State Province, South Africa. AIDS Care 2015; 27: 198-205.

25 Yang H, Li X, Stanton B, Fang X, Lin D, Naar-King S. HIVrelated knowledge, stigma, and willingness to disclose: a mediation analysis. AIDS Care 2006; 18: 717-724.

26 Mathew A S, Takalkar A M. Living with tuberculosis: the myths and the stigma from the Indian perspective. Clin Infect Dis 2007; 45: 1247 . 


\section{APPENDIX}

Information on the measurement of HIV and TB knowledge and confidentiality

\section{Knowledge about the human immunodeficiency virus}

Knowledge about the human immunodeficiency virus (HIV) was measured using 10 questions; answer categories were 'yes', 'no' and 'not sure'. Scores were added to compute a score ranging from 0 (no knowledge) to 10 (perfect knowledge).

1. Can people reduce their risk of HIV infection by using a condom every time they have sex?

2. Can HIV or AIDS (acquired immune-deficiency syndrome) be cured?

3. Is it possible to cure tuberculosis (TB) in people with HIV?

4. Is a person with HIV more likely to get TB?

5. Does antiretroviral treatment make HIV-positive people less infectious?

6. Can the HIV virus ever be transmitted from a mother to a child in the womb?

7. Is the risk of HIV transmission following needleprick or sharps injuries very small (under $0.4 \%$ risk)?

8. Should all HIV-positive women use formula feeding only for their babies?

9. Does medical male circumcision help prevent HIV-positive men from transmitting HIV?

10. Will all people who are taking antiretroviral drugs eventually develop resistance?

\section{Knowledge about tuberculosis}

Knowledge about TB was measured using 10 questions; answer categories were 'yes', 'no' and 'not sure'. Scores were added to compute a score ranging from 0 (no knowledge) to 10 (perfect knowledge).

1. Are the following symptoms used to diagnose TB?
i. Cough for $>2$ weeks
ii. Unintentional weight loss
iii. Fever for $>1$ week
iv. Night sweats
v. Nausea

2. Should TB be treated for at least 6 months?

3. Should at least four drugs be used to treat TB?

4. Do people with TB usually become less infectious within 3 weeks after initiating appropriate treatment?

5. Can people with multidrug-resistant TB be cured within 12 months?

6. Can HIV-positive health care workers (HCWs) be protected from tuberculous infection by undergoing isoniazid prophylaxis treatment?

\section{Confidentiality}

Confidentiality was measured using five questions; answering categories were 'yes', 'no' and 'not sure' (except for question 1, which only had 'yes' and 'no' answers):

1. Since you have been working at your current hospital, have you been taught about protecting the confidentiality of the HIV status of co-workers (HCWs)?

2. In your hospital is there a code of conduct (formal set of guidelines) in place for dealing with wrongful disclosure of a HCW's health information?

3. Do you think that confidentiality about HIV is maintained in your Occupational Health Unit (Sick Bay)?

4. Do you think that confidentiality about TB is maintained in your Occupational Health Unit (Sick Bay)?

5. Do you think that confidentiality about general health-related issues is maintained in your Occupational Health Unit (Sick Bay)?

\section{Analytical strategy}

In a first step, and as a theory-testing model, internal construct validity was assessed using a series of separate confirmatory factor analyses (CFAs). For each of the four stigma scales, we removed items that did not successfully load $(<0.40)$ onto the theoretical stigma domain. ${ }^{1,2}$ The fit indices used were the Tucker-Lewis Index (TLI), the comparative fit index (CFI), the root mean square error of approximation (RMSEA) and the standardized root mean square residual (SRMR).

Following the recommendations of $\mathrm{Hu}$ and Bentler, two of the following three criteria had to be met for satisfactory global model fit to be attained: CFI/TLI $\geqslant 0.95$, RMSEA $\leqslant 0.06$, and SRMR $\leqslant 0.08 .^{3}$ Other methodologists have proposed that RMSEA values $<0.08$ suggest an adequate model fit, ${ }^{4}$ and CFI and TLI values of $0.90-0.95$ are indicative of an acceptable model fit. ${ }^{1,2}$

Second, the reliability of the different stigma scales was measured using Cronbach's $\alpha$ coefficient (internal consistency). For a stigma scale to be considered consistent, the value of the coefficient must be $>0.7 .^{5}$

In a third step, we tested whether the four stigma scales had the same meaning for each professional group-patient staff (i.e., all staff directly working with patients) and support staff (administrative and supportive staff, including cleaners, clerks, etc.). This question was addressed by testing for factorial invariance-1) configural, 2) measurement and 3) scalar invariance-of the targeted construct across the two groups. Configural invariance required that stigma factors be associated with the same items 
across the two groups. Metric invariance required the corresponding factor loadings to be equal across groups, testing whether common factors had the same meaning across the groups. The final step (scalar invariance) required equal item intercepts across the groups. Where the lack of scalar invariance signals the presence of item bias (or differential item functioning), its presence states that comparison of factor means across groups is possible. ${ }^{6,7}$ The restrictions for equality of specific parameters across groups were imposed one by one, thus producing nested models that were tested against each other using $\chi^{2}$ difference testing.

Finally, we tested correlations between the different stigma scales to assess the interrelationships between scales, as well as their ability to differentiate between the different types of HIV- and TB-related stigma. We expected the TBOES and HIVOES scales to be positively correlated with the respondent's external stigmatising perceptions, attitudes and behaviours (HIVRES and TBRES), as past experiences of external stigma such as blame, rejection, intimidation, name-calling, exclusion and isolation have been shown to influence the respondents' own stigmatising perceptions, attitudes and behaviour. ${ }^{8}$ External construct validity was investigated by assessing the relationship between the different stigma subscales and relevant correlates: 1) HIV- and TB-related knowledge and 2) the level of confidentiality in the workplace, using structural equation modelling. 9,10 Based upon the literature, ${ }^{11,12}$ we expected the stigma scales (HIVOES and TBOES) assessing stigmatisation by others to be negatively correlated with the level of confidentiality, as a breach in confidentiality can be a proxy for stigmatising behaviour in the workplace. We expected the respondent's external stigmatising perceptions, attitudes and behaviours (HIVRES and TBRES) to be negatively correlated with his/her knowledge of the disease, as this relationship has been reported repeatedly. ${ }^{13-15}$ However, the workforce interviewed was rather diverse, necessitating us to assess these relationships while controlling for the age and gender of the respondent, his/her role in the facility and the level of education achieved.

\section{References}

1 Bentler P. Comparative fit indexes in structural models. Psychol Bull 1990; 107: 238-246.

2 Brown T A. Confirmatory Factor Analysis for Applied Research. Kenny D A, ed. New York, NY, USA: The Guilford Press, 2006.

$3 \mathrm{Hu} \mathrm{L}-\mathrm{T}$, Bentler P M. Cut-off criteria for fit indexes in covariance structure analysis: conventional criteria versus new alternatives. Struct Equation Model 1999; 6: 1-55.

4 Browne M, Cudeck R. Alternative ways of assessing model fit. In: Bollen K A \& Long J S, eds. Testing Structural Equation Models. Beverly Hills, CA, USA: Sage, 1993.

5 Bland J M, Douglas G A. Statistics notes: Cronbach's alpha. BMJ 1997; 314: 572.

6 Dimitrov D M. Testing for factorial invariance in the context of construct validation. Meas Eval Counsel Dev 2010; 43: 121149 .

7 Gregorich S E. Do self-report instruments allow meaningful comparisons across diverse population groups? Testing measurement invariance using the confirmatory factor analysis framework. Med Care 2006; 44 (Suppl 3): S78-S94.

8 Wouters E, Rau A, Engelbrecht M, et al. the development and piloting of parallel scales measuring external and internal HIV and tuberculosis stigma among healthcare workers in the Free State Province, South Africa. Clin Infect Dis 2016; 62 (Suppl 3): S244-S254.

9 Muthén L K, Muthén B O. MPlus User's Guide. $5^{\text {th }}$ ed. Los Angeles, CA, USA: Muthén \& Muthén, 1998-2007.

10 Terwee C B, Bot S D M, de Boer M R, et al. Quality criteria were proposed for measurement properties of health status questionnaires. J Clin Epidemiol 2007; 60: 34-42.

11 Nyblade L, Stangl A, Weiss E, Ashburn K. Combating HIV stigma in health care settings: what works? J Int AIDS Soc 2009; 12: 15 .

12 Coreil J, Mayard G, Simpson K M, Lauzardo M, Zhu Y, Weiss M. Structural forces and the production of TB-related stigma among Haitians in two contexts. Soc Sci Med 2010; 71: 1409_ 1417.

13 Fay H, Baral S, Trapence G, et al. Stigma, health care access, and HIV knowledge among men who have sex with men in Malawi, Namibia, and Botswana. AIDS Behav 2011; 15: 10881097.

14 Yang H, Li X, Stanton B, Fang X, Lin D, Naar-King S. HIVrelated knowledge, stigma, and willingness to disclose: a mediation analysis. AIDS Care 2006; 18: 717-724.

15 Mathew A S, Takalkar A M. Living with tuberculosis: the myths and the stigma from the Indian perspective. Clin Infect Dis 2007; 45: 1247 . 
CONTEXte: Des éléments récents indiquent que la stigmatisation liée au virus de l'immunodéficience humaine $(\mathrm{VIH})$ et à la tuberculose $(\mathrm{TB})$ constitue un obstacle majeur à l'utilisation des services de médecine du travail par le personnel de santé (HCW) d'Afrique du Sud. Ceci met également en lumière un manque d'outils appropriés destinés à mesurer la stigmatisation liée au VIH et à la TB parmi les HCW.

OBJECTIF: Tester quatre échelles de mesure des différents aspects de la stigmatisation-la stigmatisation extérieure des répondants (RES) et la stigmatisation extérieure d'autres personnes (OES) vis-àvis de la TB ainsi que du VIH-dans différentes catégories professionnelles de HCW.

SCHÉMA : L'étude actuelle recourt aux données d'un essai randomisé contrôlé en groupes rassemblant les données de $882 \mathrm{HCW}$ dans l'état libre d'Orange en Afrique du Sud. Les analyses factorielles de confirmation et la modélisation par équation structurelle ont été utilisées afin d'évaluer la validité et la fiabilité des échelles.

RÉSULTATS: Les quatre échelles ont montré une validité suffisante en termes de structure interne. L'analyse ultérieure a démontré que les quatre échelles présentaient une invariance métrique et les échelles OES même une invariance d'échelle à travers les groupes de patients et de personnel de soutien. Les échelles ont démontré une bonne fiabilité et validité de structure externe.

CONCLUSION: Les résultats soutiennent l'utilisation des échelles développées comme méthode de mesure de la stigmatisation vis-à-vis de la TB et du VIH parmi les HCW. Davantage de recherche est cependant nécessaire pour affiner les instruments et les tester dans différents pays à ressources limitées.
Marco de referencia: Pruebas científicas recientes indican que la estigmatización asociada con la infección por el virus de la inmunodeficiencia humana (VIH) y la tuberculosis (TB) constituye un obstáculo central a la utilización de los servicios de medicina del trabajo conexos por parte del personal sanitario (HCW) en Suráfrica. La situación pone de relieve además la carencia de instrumentos adecuados que permitan medir el grado de estigmatización relacionada con estas dos afecciones en los HCW.

OBJETIVO: Ensayar cuatro escalas que miden aspectos diferentes de la estigmatización asociada con la TB y la infección por el VIH (los estigmas externos de las personas que responden a las preguntas [RES] y los estigmas externos que estas personas perciben en los demás [OES]), en diferentes categorías de HCW.

MÉTODO: En la presente investigación se utilizaron datos de un estudio comparativo aleatorizado por conglomerados que recoge datos de $882 \mathrm{HCW}$ en la provincia del Estado Libre de Suráfrica. Se aplicaron modelos de ecuaciones estructurales con análisis factoriales confirmatorios a fin de evaluar la validez y la fiabilidad de las escalas.

RESULTADOS: Las cuatro escalas ofrecieron una adecuada validez interna del constructo. Los análisis siguientes demostraron que las cuatro escalas presentaban invarianza métrica y las escalas sobre los estigmas percibidos exhibieron incluso invarianza de escala, cuando se utilizaban en diferentes grupos de HCW y personal auxiliar. Se observó una adecuada fiabilidad y validez externa del constructo de las escalas. CONCLUSIÓN: Los resultados del estudio respaldan la utilización de las escalas elaboradas como método de medición de la estigmatización asociada con la TB y la infección por el VIH en los HCW. No obstante, se precisan nuevas investigaciones que afinen estos instrumentos y los pongan a prueba en diferentes países con recursos limitados. 